Prepared in cooperation with the New Hampshire Geological Survey

\title{
Geophysical Logging of Bedrock Wells for Geothermal Gradient Characterization in New Hampshire, 2013
}

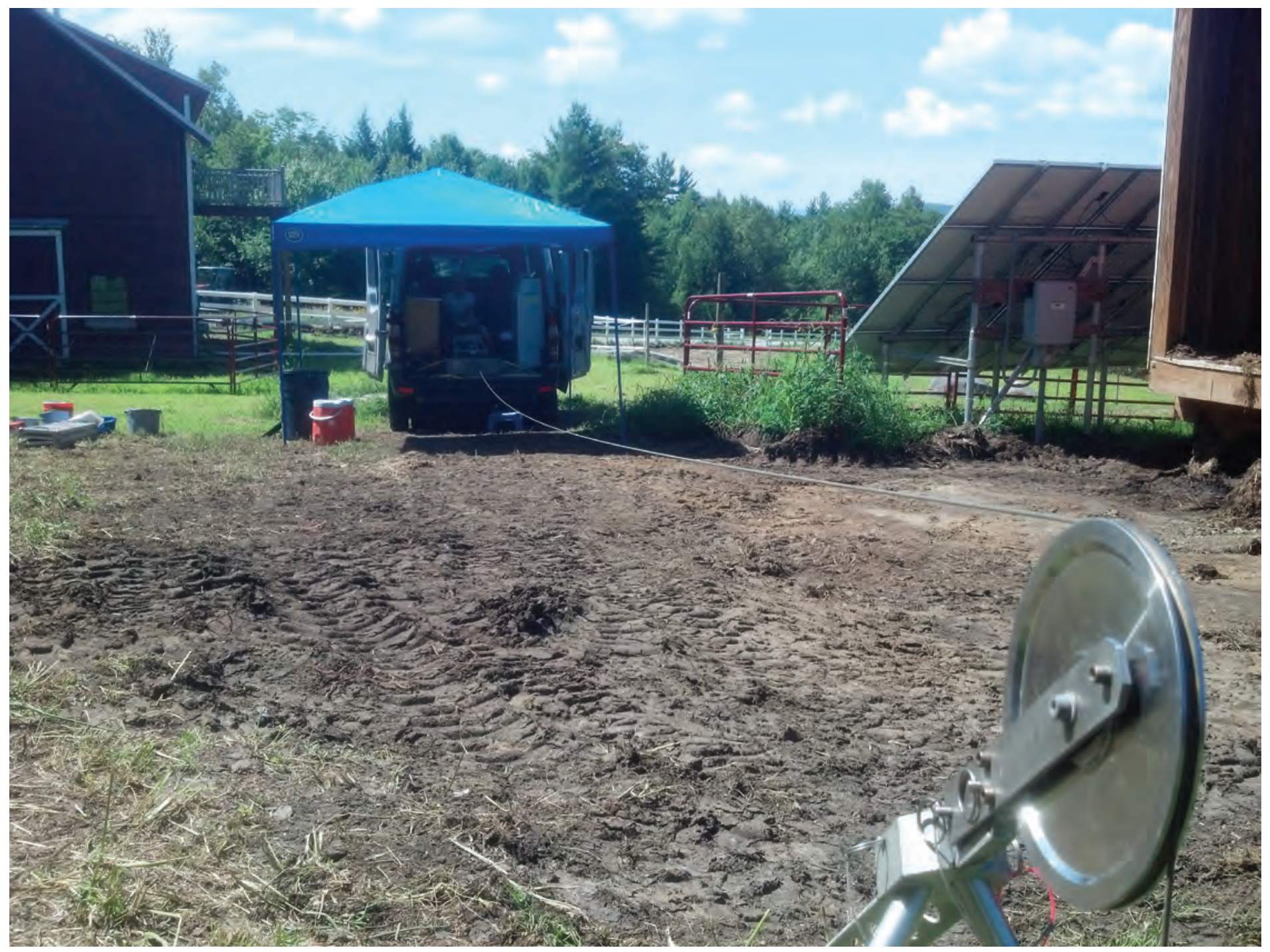

Data Series 823

U.S. Department of the Interior

U.S. Geological Survey 
Cover. Borehole logging cable and pulley at North Conway New Hampshire. 


\section{Geophysical Logging of Bedrock Wells for Geothermal Gradient Characterization in New Hampshire, 2013}

By James R. Degnan, Gregory Barker, Neil Olson, and Leland Wilder

Prepared in cooperation with the New Hampshire Geological Survey

Data Series 823 


\title{
U.S. Department of the Interior SALLY JEWELL, Secretary
}

\section{U.S. Geological Survey Suzette M. Kimball, Acting Director}

\author{
U.S. Geological Survey, Reston, Virginia: 2014
}

For more information on the USGS - the Federal source for science about the Earth, its natural and living resources, natural hazards, and the environment, visit http://www.usgs.gov or call 1-888-ASK-USGS.

For an overview of USGS information products, including maps, imagery, and publications, visit http://www.usgs.gov/pubprod

To order this and other USGS information products, visit http://store.usgs.gov

Any use of trade, firm, or product names is for descriptive purposes only and does not imply endorsement by the U.S. Government.

Although this information product, for the most part, is in the public domain, it also may contain copyrighted materials as noted in the text. Permission to reproduce copyrighted items must be secured from the copyright owner.

Suggested citation:

Degnan, J.R., Barker, Gregory, Olson, Neil, and Wilder, Leland, 2014, Geophysical logging of bedrock wells for geothermal gradient characterization in New Hampshire, 2013: U.S. Geological Survey Data Series 823, 19 p., at http:// dx.doi.org/10.3133/ds823. 


\section{Acknowledgments}

The authors thank all who assisted with and supported this project. Permission and support from private land owners who allowed access to their wells made data collection possible. Equipment and technical advice provided by Carole Johnson of the U.S. Geological Survey (USGS) helped in the understanding of logging results and data processing. Equipment provided by John Williams and Alton Anderson of the USGS made high-quality data collection possible. Reviews of this report were done by Stephen Curtin and Richard Moore. Technical advice from Paul Staples of Mount Sopris Instruments was helpful for temperature calibration. Kelseyann Regan and Ellen Finch of the USGS provided assistance with logging. 
THIS PAGE INTENTIONALLY LEFT BLANK 


\section{Contents}

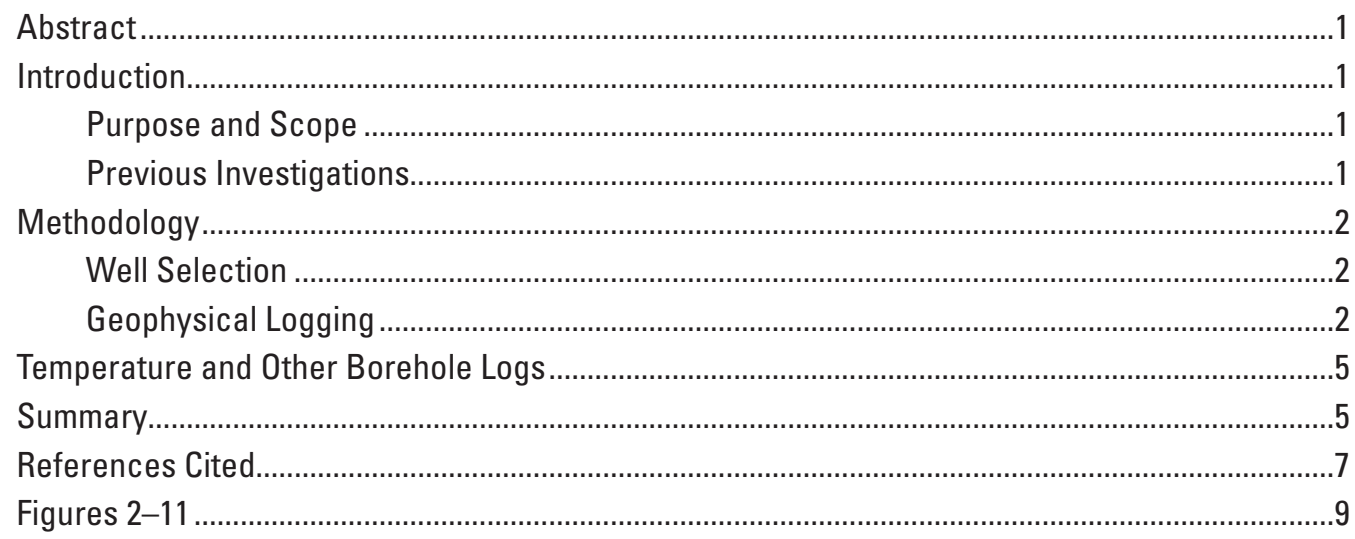

\section{Figures}

1. Map showing locations of bedrock wells logged for geothermal gradient characterization in New Hampshire in 2013.

2. Geophysical logs from bedrock well TZW 150 in Tuftonboro, New Hampshire, 2013.....10

3. Geophysical logs from bedrock well TZW 149 in Tuftonboro, New Hampshire, 2013.....11

4. Geophysical logs from bedrock well MWW 269 in Moultonborough, New Hampshire, 2013.

5. Geophysical logs from bedrock well CWW 246 in North Conway, New Hampshire, 2013

6. Geophysical logs from bedrock well CWW 247 in North Conway, New Hampshire, 2013

$$
\text { (1) }
$$
, 9

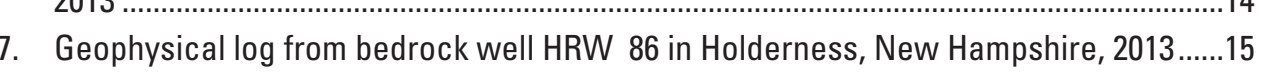

8. Geophysical log from bedrock well WPW 1068 in Windham, New Hampshire, 2013.....16

9. Geophysical logs from bedrock well HUW 261 in Hopkinton, New Hampshire, 2013.....17

10. Geophysical logs from bedrock well BBW 283 in Barrington, New Hampshire, 2013. ..18

11. Geophysical logs from bedrock well HUW 262 in Hopkinton, New Hampshire, 2013.....19

\section{Tables}

1. Information for bedrock wells logged for geothermal gradient characterization in New Hampshire, in 2013 ...........................................................................................

2. Summary of depth, temperature, and gamma properties of wells logged in $2013 \ldots \ldots \ldots . . .6$ 


\section{Conversion Factors and Datum}

Inch/Pound to SI

\begin{tabular}{lll}
\hline \multicolumn{1}{c}{ Multiply } & By & \multicolumn{1}{c}{ To obtain } \\
\hline inch (in.) & Length & \\
foot (ft) & 2.54 & centimeter $(\mathrm{cm})$ \\
mile (mi) & 0.3048 & meter $(\mathrm{m})$ \\
\hline & 1.609 & kilometer $(\mathrm{km})$ \\
\hline foot per minute $(\mathrm{ft} / \mathrm{min})$ & Rate & \\
gallon per minute $(\mathrm{gal} / \mathrm{min})$ & 0.3048 & meter per minute $(\mathrm{m} / \mathrm{min})$ \\
\hline
\end{tabular}

Temperature in degrees Celsius $\left({ }^{\circ} \mathrm{C}\right)$ may be converted to degrees Fahrenheit $\left({ }^{\circ} \mathrm{F}\right)$ as follows:

${ }^{\circ} \mathrm{F}=\left(1.8 \times^{\circ} \mathrm{C}\right)+32$

Temperature in degrees Fahrenheit $\left({ }^{\circ} \mathrm{F}\right)$ may be converted to degrees Celsius $\left({ }^{\circ} \mathrm{C}\right)$ as follows:

${ }^{\circ} \mathrm{C}=\left({ }^{\circ} \mathrm{F}-32\right) / 1.8$

Vertical coordinate information is referenced to the North American Vertical Datum of 1988 (NAVD 88).

Horizontal coordinate information is referenced to the North American Datum of 1983 (NAD 83).

Specific conductance is given in microsiemens per centimeter at 25 degrees Celsius $(\mu \mathrm{S} / \mathrm{cm}$ at $\left.25^{\circ} \mathrm{C}\right)$. 


\title{
Geophysical Logging of Bedrock Wells for Geothermal Gradient Characterization in New Hampshire, 2013
}

\author{
By James R. Degnan', Gregory Barker ${ }^{2}$, Neil Olson², and Leland Wilder ${ }^{2}$
}

\begin{abstract}
The U.S. Geological Survey, in cooperation with the New Hampshire Geological Survey, measured the fluid temperature of groundwater and other geophysical properties in 10 bedrock wells in the State of New Hampshire in order to characterize geothermal gradients in bedrock. The wells selected for the study were deep (five ranging from 375 to 900 feet and five deeper than 900 feet) and 6 had low water yields, which correspond to low groundwater flow from fractures. This combination of depth and low water yield reduced the potential for flow-induced temperature changes that would mask the natural geothermal gradient in the bedrock. Eight of the wells included in this study are privately owned, and permission to use the wells was obtained from landowners before geophysical logs were acquired for this study. National Institute of Standards and Technology thermistor readings were used to adjust the factory calibrated geophysical log data. A geometric correction to the gradient measurements was also necessary due to borehole deviation from vertical.

Maximum groundwater temperatures at the bottom of the logs ranged from 11.2 to 15.4 degrees Celsius. Geothermal gradients were generally higher than those typically reported for other water wells in the United States. Some of the high gradients were associated with high natural gamma emissions. Groundwater flow was discernible in 4 of the 10 wells studied but only obscured the part of the geothermal gradient signal where groundwater actually flowed into, out of, or through the well. Temperature gradients varied by mapped bedrock type but can also vary by localized differences in mineralogy or rock type within the wells.
\end{abstract}

\section{Introduction}

Information collected from geophysical logs, including groundwater temperature logs, can be used to assess the

\footnotetext{
${ }^{1}$ U.S. Geological Survey.
}

${ }^{2}$ New Hampshire Geological Survey. development potential of geologic formations as sources of geothermal energy. The temperature of groundwater within wells, in the absence of significant groundwater flow, reflects the temperature of the surrounding geologic formations. Geothermal gradients, defined as the increase in temperature with depth, from various rock units measured in mines and drill holes around the world range from 0.46 to 2.29 degrees Celsius $\left({ }^{\circ} \mathrm{C}\right)$ per 100 feet $(\mathrm{ft})$ of depth (Skinner and Porter, 1992). The typical range of geothermal gradients observed in groundwater wells is 0.47 to $0.60{ }^{\circ} \mathrm{C}$ per $100 \mathrm{ft}$ (Keys, 1990), which is slightly lower than the range 0.56 to $0.72{ }^{\circ} \mathrm{C}$ per $100 \mathrm{ft}$ that was documented in Degnan and others, (2012). Degnan and others (2012) described an initial assessment of geothermal gradients in selected wells in New Hampshire. Ten additional wells were analyzed in the state in 2013 by the U.S. Geological Survey in cooperation with the New Hampshire Geological Survey (NHGS).

\section{Purpose and Scope}

The NHGS is interested in the potential for geothermal energy production from the bedrock in the State. The purpose of this report is to present geophysical data that can be used to characterize lithology and geothermal gradients in crystalline bedrock wells in the State of New Hampshire. The information in this report can help researchers and decision makers to evaluate the geothermal potential of the bedrock in New Hampshire. For this study, wells were logged to determine temperature and other geophysical properties, and the data collected will become part of a national inventory of data used to evaluate geothermal potential across the United States. Geophysical log data in the log ASCII standard (LAS) format are part of this report. The digital data are available at http://pubs.usgs.gov/ds/823/.

\section{Previous Investigations}

There is a long history of efforts to study the geothermal properties of rocks in New Hampshire. Geothermal gradients within the Earth's crust are driven by the conduction of heat from the core that travels with convection currents through the mantle (Skinner and Porter, 1992). Variations in geothermal 
gradients are attributable to the location of the convection cells, crustal thickness, rock type, and heat production by the decay of radioactive minerals. Birch and others (1968) reported geothermal gradients between 0.55 and $0.67^{\circ} \mathrm{C}$ per $100 \mathrm{ft}$ for sites in central New Hampshire. Degnan and others (2012 and 2013) reported mean geothermal gradients between 0.56 and $0.72{ }^{\circ} \mathrm{C}$ per $100 \mathrm{ft}$ for sites in Hillsboro and Belknap Counties, New Hampshire. Kim and others (2013) reported preliminary gradients between 0.21 and $0.47^{\circ} \mathrm{C}$ per $100 \mathrm{ft}$ from temperatures measured in wells in the State of Vermont. Geothermal gradients as high as $0.7^{\circ} \mathrm{C}$ per $100 \mathrm{ft}$ with an average of $0.5^{\circ} \mathrm{C}$ per $100 \mathrm{ft}$ were reported for wells logged in Maine (Keith Sorota, Hager GeoScience, Inc., written commun., 2014).

Previous geothermal studies in New Hampshire, focusing largely on the Conway granite in the White Mountains of New Hampshire, were summarized by Wilder (2003). High heat production in plutonic bedrock in New Hampshire is associated with the decay of radioactive minerals, which was quantified by Billings and Keevil (1945). Hoag and Stewart (1977) provided a detailed lithologic and geophysical description of the geothermal test hole in Redstone (a village in Conway, New Hampshire), including a temperature log. The Redstone geothermal test hole had an average gradient of $0.85^{\circ} \mathrm{C}$ per $100 \mathrm{ft}$. Caruso and Simmons (1985) investigated the distribution of uranium in the Redstone geothermal test hole core. Uranium is found within minerals and microfractures that were emplaced and formed during, and likely after, crystallization of the granite found in the Redstone test hole. Redistribution of uranium from hydrothermal fluid circulation after crystallization can, in part, account for the high concentrations.

\section{Methodology}

Ten wells were selected for geophysical logging. Fluid and physical borehole property values, including fluid temperature, fluid conductance, natural gamma radiation emissions, hole diameter (caliper log), and inclination, were recorded in logs. An optical televiewer (OTV) log was used to record an oriented 360-degree image of the structure and lithology in the boreholes. Well construction data were entered into the U.S. Geological Survey (USGS) groundwater site inventory (GWSI) database. Log data are stored and archived in log ASCII standard (LAS) format and are available as part of this report at http://pubs.usgs.gov/ds/823/.

\section{Well Selection}

The selection of wells was made by the NHGS on the basis of depth, bedrock type, accessibility, and lack of pumps and plumbing in the well. Wells with a low potential for intraborehole flow (low yield, less than a gallon per minute) were also given a higher priority for logging. The Water
Well Inventory Program database (Chormann, 2001, and New Hampshire Department of Environmental Services, undated) of the State of New Hampshire was queried to find candidate wells. Eight of the wells included in this study are privately owned. Permission to use the wells was obtained from landowners or managers. Ten bedrock wells (from 375 to greater than 2,200 feet in depth), including six with low water yield, were identified (table 1).

In all, 10 wells were logged in central and southeastern New Hampshire (fig. 1). The locations of wells were viewed in a geographic information system along with data on bedrock formation (Lyons and others, 1997; Bennett and others, 2006) to determine the bedrock types that may occur either within or near the well on the basis of geologic information that is mapped at 1:250,000 scale. The actual bedrock formation within the well may vary owing to local scale heterogeneity of the rocks. Wells drilled in igneous rocks, as determined from the State geologic map, were given the highest priority for logging because of the high potential for heat production associated with the presence of radioactive minerals (Roy and others, 1968). Wells completed in metamorphic formations adjacent to targeted igneous bodies were also identified so that potential heat propagation into these bodies could be better understood.

\section{Geophysical Logging}

Borehole fluid temperature data were collected at 10 wells using a Mount Sopris Instrument Company 2FPA1000 probe with a resolution of $0.01{ }^{\circ} \mathrm{C}$. Factory calibrations with reported 99-percent accuracy were used for logging in the field. However, before logging each well, temperature readings from the probe were recorded in concert with a National Institute of Standards and Technology thermistor $\left(0.05^{\circ} \mathrm{C}\right.$ accuracy, $0.001{ }^{\circ} \mathrm{C}$ resolution) with current certification to ensure the accuracy of the temperature values. The median difference in temperature between the thermistor and probe readings from warm- and cold-water baths (designed to bracket the temperatures expected in the wells) was later used to adjust the factory calibrated data from the probe by applying a two-point linear correction. Temperature gradients were determined from temperature measurement differences at $100-\mathrm{ft}$ intervals below the depth where the gradient was observed to be increasing. The borehole deviation from vertical, including inclination, was used to produce a geometric correction to the gradient measurement.

In addition to temperature logs, geophysical logs, including fluid conductance, natural gamma radiation (gamma ray emissions), 3-arm caliper, inclination, and optical televiewer, were collected. Changes in gamma ray emissions in the gamma log indicate changes in mineralogy and bedrock type with depth. The caliper log records hole diameter and indicates locations of greater borehole width where the bedrock may be fractured. Fluid conductance logs indicate groundwater flow in a borehole and can indicate 


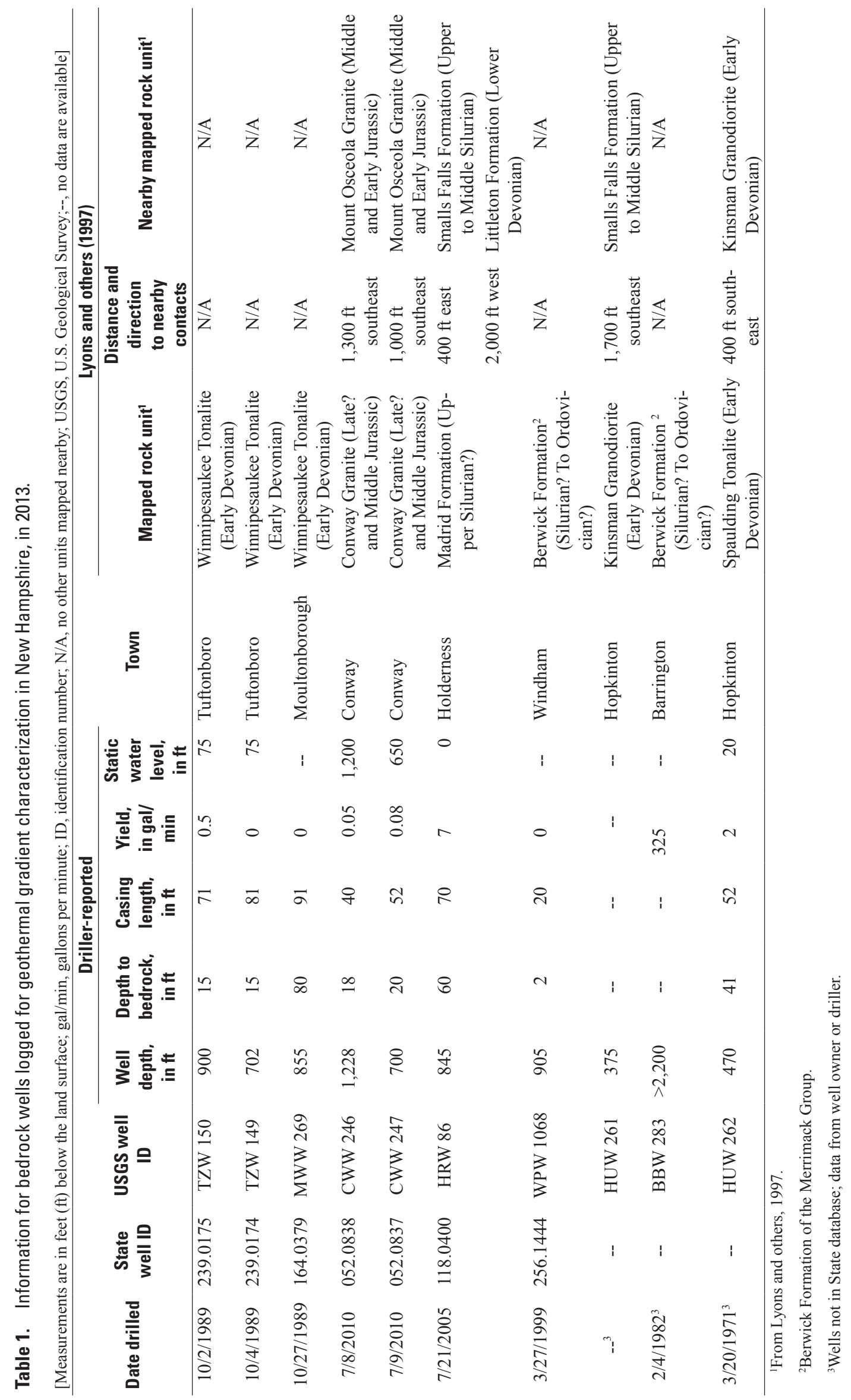




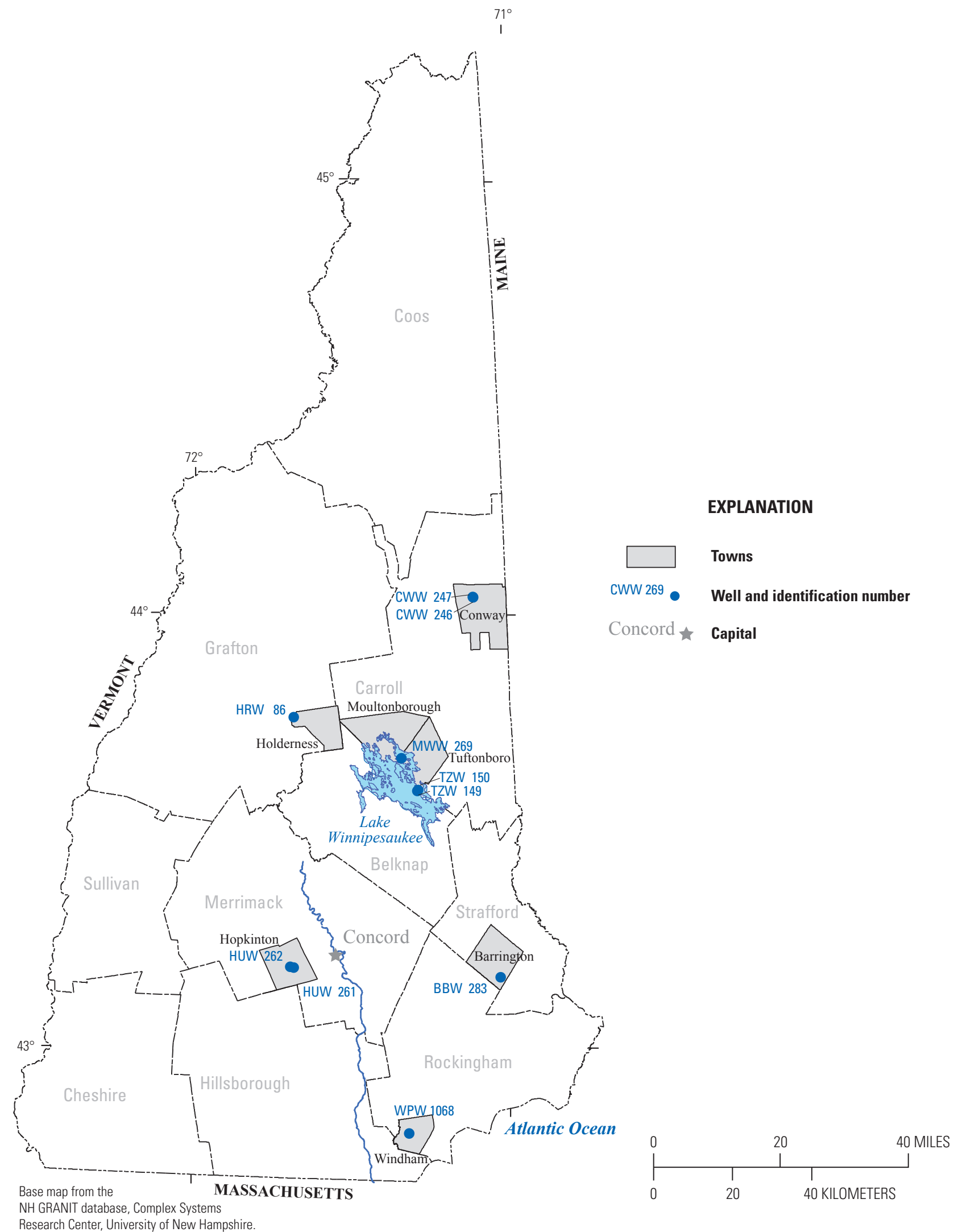

Figure 1. Locations of bedrock wells logged for geothermal gradient characterization in New Hampshire in 2013. Well identification numbers are from the U.S. Geological Survey groundwater site inventory database. 
where the geothermal gradient information may be masked. Fluid temperature and conductance were logged first, going down the hole; logging rates were between 11 and 12 feet per minute. Results from well logging are presented for each borehole investigated. Descriptions of standard boreholegeophysical logging methods and interpretation can be found in Keys (1990). The methods of collection and analysis of OTV logs are described by Johnson and others (2005).

\section{Temperature and Other Borehole Logs}

Ten wells that were drilled into igneous or metamorphic rock in New Hampshire were logged with a temperature probe to create a temperature profile of the water column with depth (figs. 2-11). Fluid conductance, natural gamma radiation (gamma ray emissions), 3-arm caliper, inclination, and optical-televiewer geophysical logs were also collected. The digital data are available at $\mathrm{http}: / /$ pubs.usgs.gov/ds/823/. The following is a brief description of the results. In wells with minimal intraborehole flow and very low yield (less than a gallon per minute), the water temperature can be assumed to represent the bedrock temperature, which is influenced by the Earth's geothermal gradient. A two-point linear correction to the factory calibrated data was made on the basis of low and high temperature calibration-check measurements that were made in the field. The 2PFA-1000 fluid temperature probe data were calibrated and adjusted using a low and a high correction of $-3.7^{\circ} \mathrm{C}$ and $+1.3{ }^{\circ} \mathrm{C}$. All of the wells had some degree of borehole deviation from vertical, including inclination, but well CWW 246 had a maximum inclination of $56^{\circ}$, which highlighted the need for a geometric correction to the temperature gradient measurement. A true vertical depth was calculated from the deviation data and used to calculate the gradients. All well depths presented are referenced to the top of the casing.

Log depths ranged from 368 to $1,223 \mathrm{ft}$ below the top of the casing, and the mean well water temperature gradients ranged from 0.45 to $0.80^{\circ} \mathrm{C}$ per $100-\mathrm{ft}$ depth (table 2). The minimum temperatures measured near the top of the wells ranged from 7.5 to $10.2^{\circ} \mathrm{C}$, and the maximum temperatures measured at the bottom of the wells ranged from 11.2 to $15.4^{\circ} \mathrm{C}$. Warm temperatures measured near the top of the water column were due to seasonal surface temperatures and were not included in the data summary of gradient calculations.

Intraborehole flow was indicated by deviation of the temperature and (or) conductivity logs in 4 of the 10 wells logged. Deflections in the fluid temperature gradient and conductivity from well MWM 269 in Moultonborough indicate that there may be groundwater flow into or out of the borehole at 366 and $513 \mathrm{ft}$ in the well (fig. 4). The drop in fluid conductance in well CWW 246 in Conway below 1,204 ft indicates possible groundwater flow into or out of the borehole (fig. 5). The fluid conductivity change at $173 \mathrm{ft}$ in well CWW
247 in North Conway indicates flow may be entering or exiting the borehole here (fig. 6). The fluid conductivity log from well WPW 1068 in Windham indicates flow at depths of 33 and $64 \mathrm{ft}$ below the top of the casing (fig. 8). The gradients show an increase in temperature with depth, even in cases where groundwater flow may slightly affect the temperature measurement in small parts of these wells.

Wells CWW 247 and CWW 246 in North Conway had the highest mean gamma responses (291 and 288 counts per second, respectively). Well CWW 247 had a higher gamma response at depths from around $50 \mathrm{ft}$ to $300 \mathrm{ft}$ below the top of the casing, which corresponds to a rock with a red color observed in the OTV log. This well also has the highest mean gradient (table 2).

\section{Summary}

Geophysical logs were obtained from 10 bedrock wells during an investigation by the U.S. Geological Survey and the New Hampshire Geological Survey to characterize geothermal gradients in bedrock in New Hampshire. The well temperatures measured at the bottom of the logged intervals ranged from 11.2 to 15.4 degrees Celsius $\left({ }^{\circ} \mathrm{C}\right)$. The coldest temperatures, measured near the top of the wells, ranged from 7.5 to $10.2{ }^{\circ} \mathrm{C}$. Mean geothermal gradients ranged from 0.45 to $0.80^{\circ} \mathrm{C}$ per 100 feet (ft). These gradients are close in value to (or higher than) the range $\left(0.47\right.$ to $0.60{ }^{\circ} \mathrm{C}$ per $100 \mathrm{ft}$ ) previously identified (Keys, 1990) for water wells in the United States and are similar in range to those reported for other wells in New Hampshire (Birch and others, 1968; Degnan and others, 2012).

Well CWW 247 in North Conway had the highest mean geothermal gradient, $0.80^{\circ} \mathrm{C}$ per $100 \mathrm{ft}$, and the highest mean gamma response (291 counts per second). The second highest mean natural gamma radiation count (288 counts per second) was measured in an adjacent well CWW 246. Well MWW 269 in Moultonborough had the highest maximum and second highest mean gradients per 100-ft interval of the wells logged in this study, $0.91{ }^{\circ} \mathrm{C}$ and $0.79{ }^{\circ} \mathrm{C}$, respectively. This is consistent with the geothermal gradient observed in the same bedrock unit from a methane-producing water well in Wolfeboro, New Hampshire (Degnan and others, 2008). The mapped bedrock units at the two wells with the highest geothermal gradients are the Conway Granite (Late? and Middle Jurassic) and the Winnipesaukee Tonalite (Early Devonian) (Lyons and others, 1997), respectively.

Possible intraborehole groundwater flow was indicated in 4 of the 10 wells logged, based on deviation of the temperature and (or) conductivity logs; the four wells are MWW 269, CWW 246, CWW 247, and WPW 1068. Fluid conductance logs were used to corroborate the temperature logs at two of the wells. Groundwater flow may slightly affect the measurement of the geothermal gradient in portions of these 


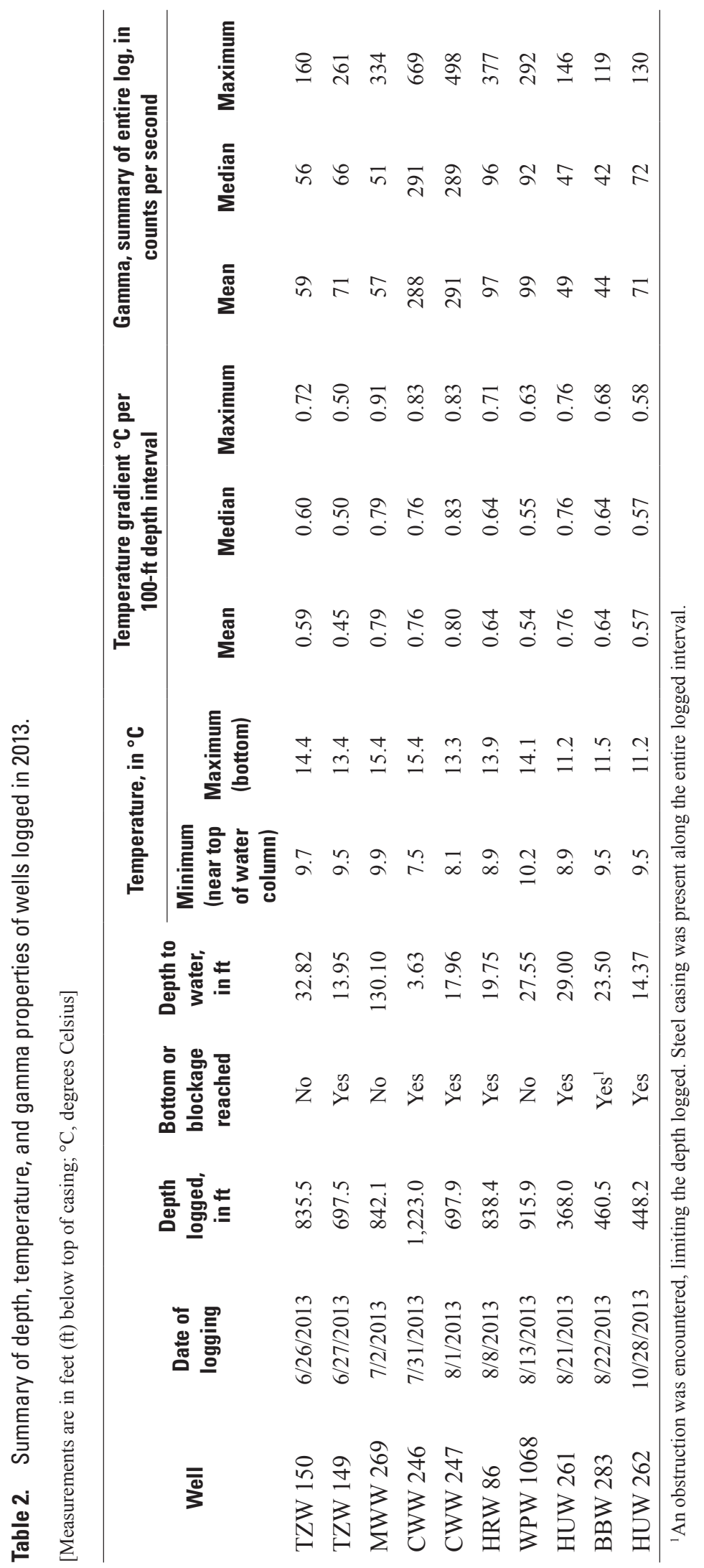


wells but does not obscure the overall gradient. In general, the gradients show an increase in temperature with depth.

The two adjacent wells logged in Tuftonboro, New Hampshire, had among the lowest temperature gradients measured. The lowest temperature gradient in the study was measured at TZW 149 with a mean of $0.45{ }^{\circ} \mathrm{C}$ per $100 \mathrm{ft}$ of depth. The bedrock at this location is mapped as Winnipesaukee Tonalite (Early Devonian) (Lyons and others, 1997), which also has some of the highest geothermal gradients measured in New Hampshire.

\section{References Cited}

Bennett, D.S., Wittkop, C.A., and Dicken, C.L., 2006, Bedrock geologic map of New Hampshire-A digital representation of the Lyons and others 1997 map and ancillary files: U.S. Geological Survey Data Series 215, CD-ROM, scale 1:250,000.

Billings, M.P., and Keevil, N.B., 1945, Petrography and radioactivity of four Paleozoic magma series in New Hampshire: Geological Society of America Bulletin, v. 57, no. 9, p. 797-828.

Birch, F., Roy, R.F., and Decker, E.R., 1968, Heat flow and thermal history in New York and New England, in Zen, E-an, ed., Studies of Appalachian geology—Northern and maritime: New York, Wiley, Interscience Publishers, $p$. 437-451.

Chormann, F.H. Jr., 2001, New Hampshire water well inventory: National Ground Water Association AGWSE Meeting and Conference, Program with Abstracts, December 7-9, 2001, Nashville, Tenn., p. 19-20.

Caruso, Louis, and Simmons, Gene, 1985, Uranium and microcracks in a 1,000-meter core, Redstone, New Hampshire: Contributions to Mineralogy and Petrology, v. 90, no. 1, p. 1-17.

Degnan, J.R., Walsh, G.J., Flanagan, S.M., and Burruss, R.C., 2008, Bedrock, borehole, and water-quality characterization of a methane-producing water well in Wolfeboro, New Hampshire: U.S. Geological Survey Open-File Report 2008-1333, 47 p., accessed January 31, 2014, at http://pubs. usgs.gov/of/2008/1333/.

Degnan, J.R., Barker, Gregory, Olson, Neil, and Wilder, Leland, 2012, Temperature logging of groundwater in bedrock wells for geothermal gradient characterization in New Hampshire, 2012: U.S. Geological Survey Data Series 728, 19 p., accessed January 31, 2014, at http://pubs.usgs.gov/ $\mathrm{ds} / 728 /$.
Degnan, J.R., Barker, Gregory, Olson, Neil, and Wilder, Leland, 2013, Temperature logging of groundwater in wells to measure bedrock geothermal gradients in New Hampshire, 2012 [abs.]: Geological Society of America Annual Meeting, 48th, Northeastern Section, March 18-20, 2013 Bretton Woods, N.H., accessed January 31, 2014, at http:// nh.water.usgs.gov/Publications/abstracts/jrd_gsa13.htm.

Hoag, R.B., and Stewart, G.W., 1977, Preliminary petrographic and geophysical interpretation of the exploratory geothermal drill hole and core, Redstone, New Hampshire: Durham, N.H., University of New Hampshire, 128 p.

Johnson, C.D., Joesten, P.K., and Mondazzi, R.A., 2005, Borehole-geophysical and hydraulic investigation of the fractured-rock aquifer near the University of Connecticut landfill, Storrs, Connecticut, 2000 to 2001: U.S. Geological Survey Water-Resources Investigations Report 03-4125, $133 \mathrm{p}$.

Keys, W.S., 1990, Borehole geophysics applied to groundwater investigations: U.S. Geological Survey Techniques of Water-Resources Investigations, book 2, chap. E2, 150 p.

Kim, Jonathan, Romanowicz, E.A., and Mehrtens, Charlotte, 2013, Using deep bedrock well logs to constrain stratigraphic and structural problems in Vermont [abs.]: Conference on Groundwater in Fractured Rock and Sediments, Sept 23-24, 2013, Burlington, Vt.: National Ground Water Association, accessed January 14, 2014, at https://ngwa. confex.com/ngwa/frc13/webprogram/Paper9249.html.

Lyons, J.B., Bothner, W.A., Moench, R.H., and Thompson, J.B., 1997, Bedrock geologic map of New Hampshire: U.S. Geological Survey Special Map, 2 sheets, scale 1:250,000.

New Hampshire Department of Environmental Services, [n.d.], Water well inventory program: New Hampshire Department of Environmental Services, accessed September 27, 2012, at http://des.nh.gov/organization/commissioner/ gsu/wwip/index.htm.

Roy, R.F., Blackwell, D.D., and Birch, Francis, 1968, Heat generation of plutonic rocks and continental heat flow provinces: Earth and Planetary Science Letters, v. 5, p. 1-12.

Skinner, B.J., and Porter, S.C., 1992, The dynamic earth-An introduction to physical geology ( $2 \mathrm{~d}$ ed.): New York, Wiley, $569 \mathrm{p}$.

Wilder, Lee, 2003, Conway granite geothermal drilling project: Granite State Geologist, no. 41, summer, p. 10-13. 
THIS PAGE INTENTIONALLY LEFT BLANK 
Figures 2-11 


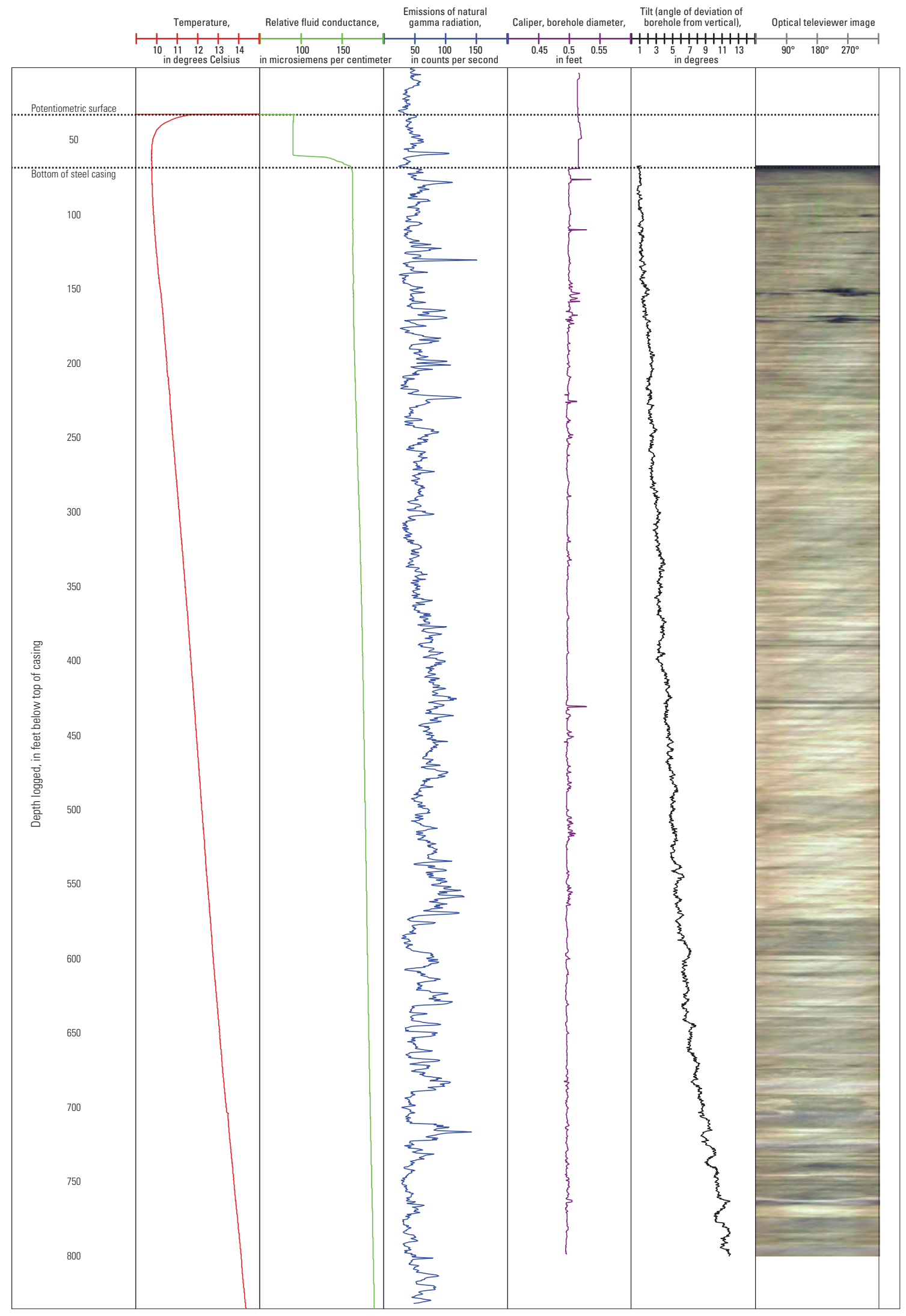

Figure 2. Bedrock well TZW 150 in Tuftonboro, New Hampshire, 2013. 


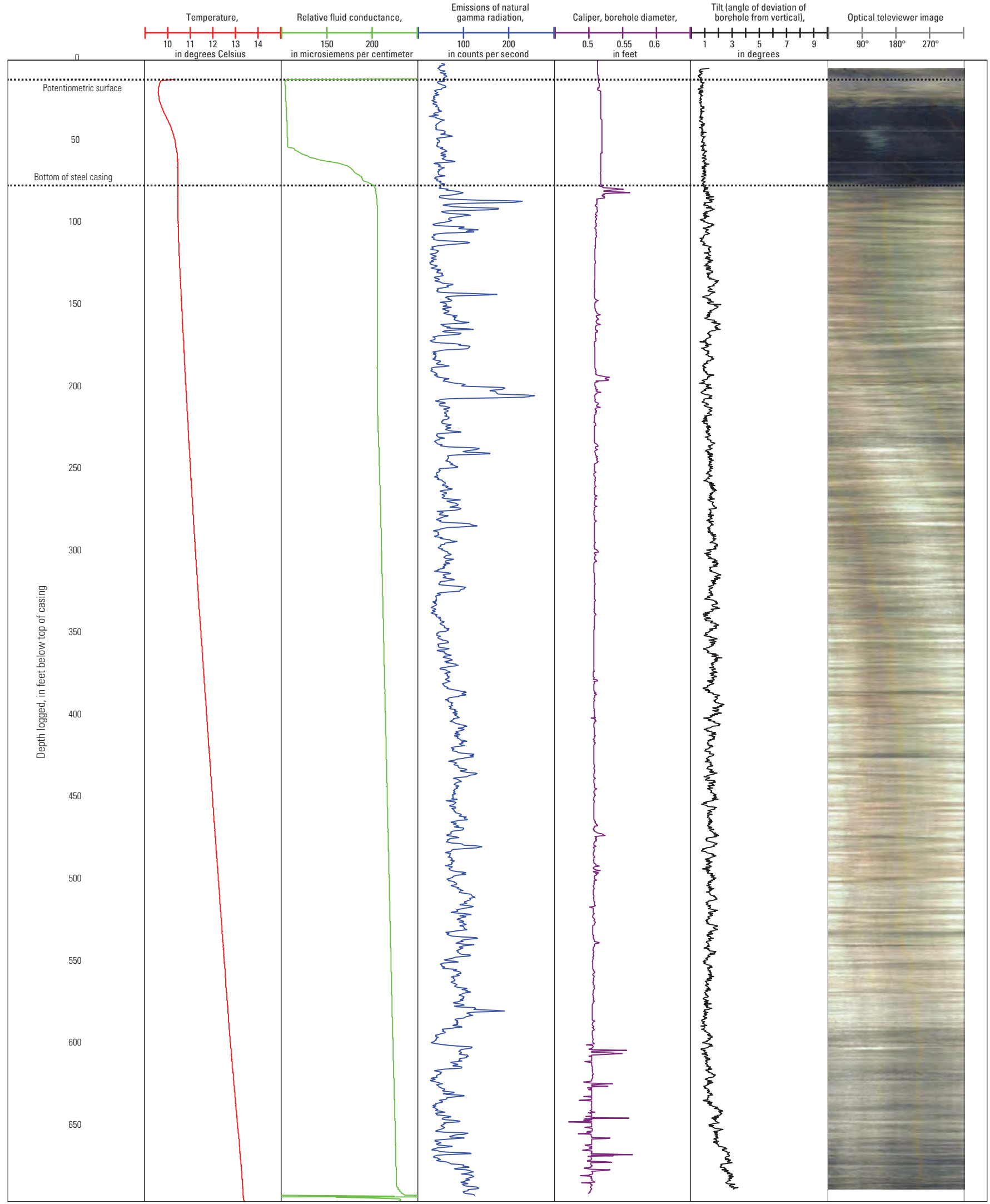

Figure 3. Bedrock well TZW 149 in Tuftonboro, New Hampshire, 2013. 


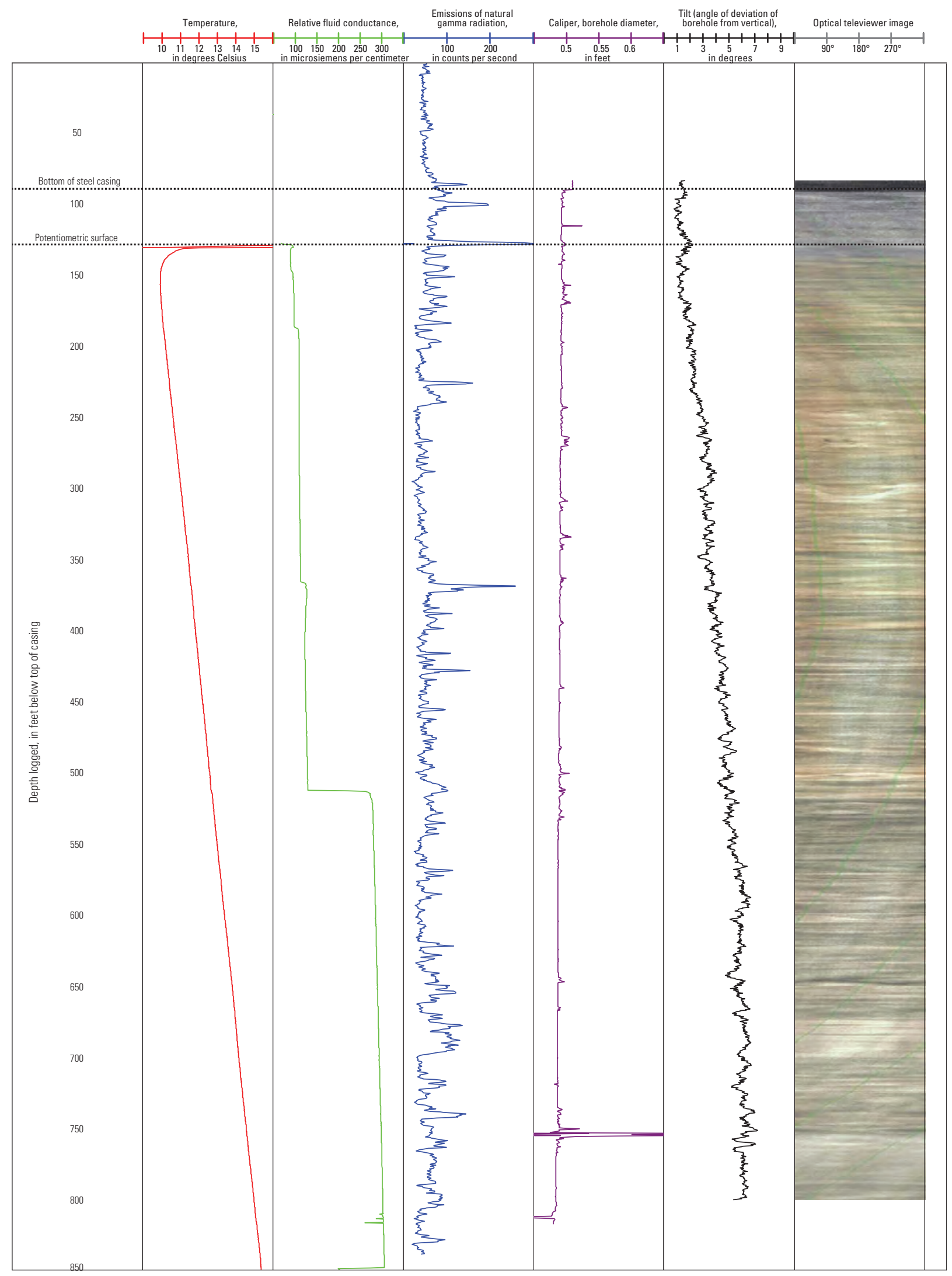

Figure 4. Bedrock well MWW 269 in Moultonborough, New Hampshire, 2013. 


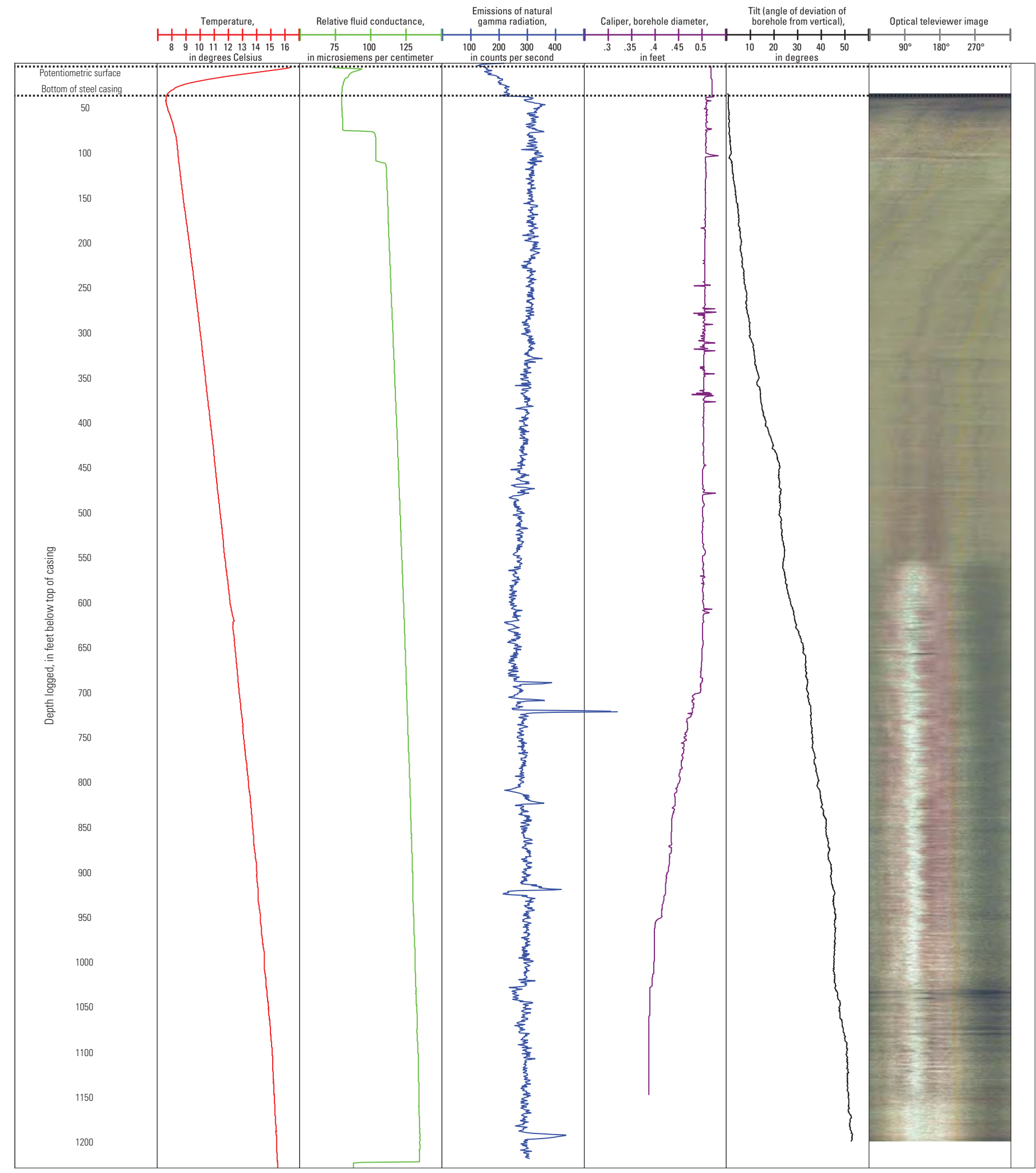

Figure 5. Bedrock well CWW 246 in North Conway, New Hampshire, 2013. 


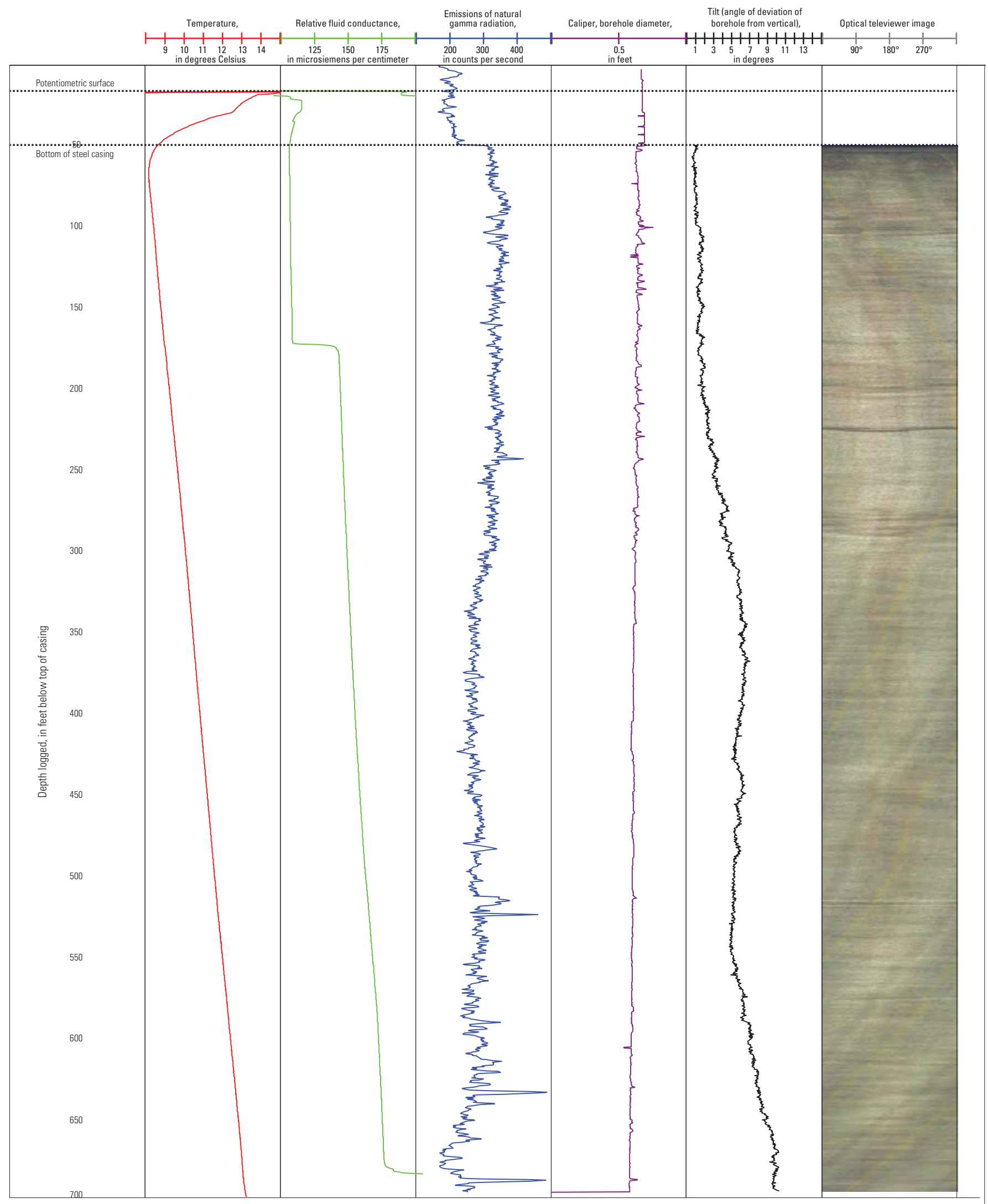

Figure 6. Bedrock well CWW 247 in North Conway, New Hampshire, 2013. 
Figures 2-11

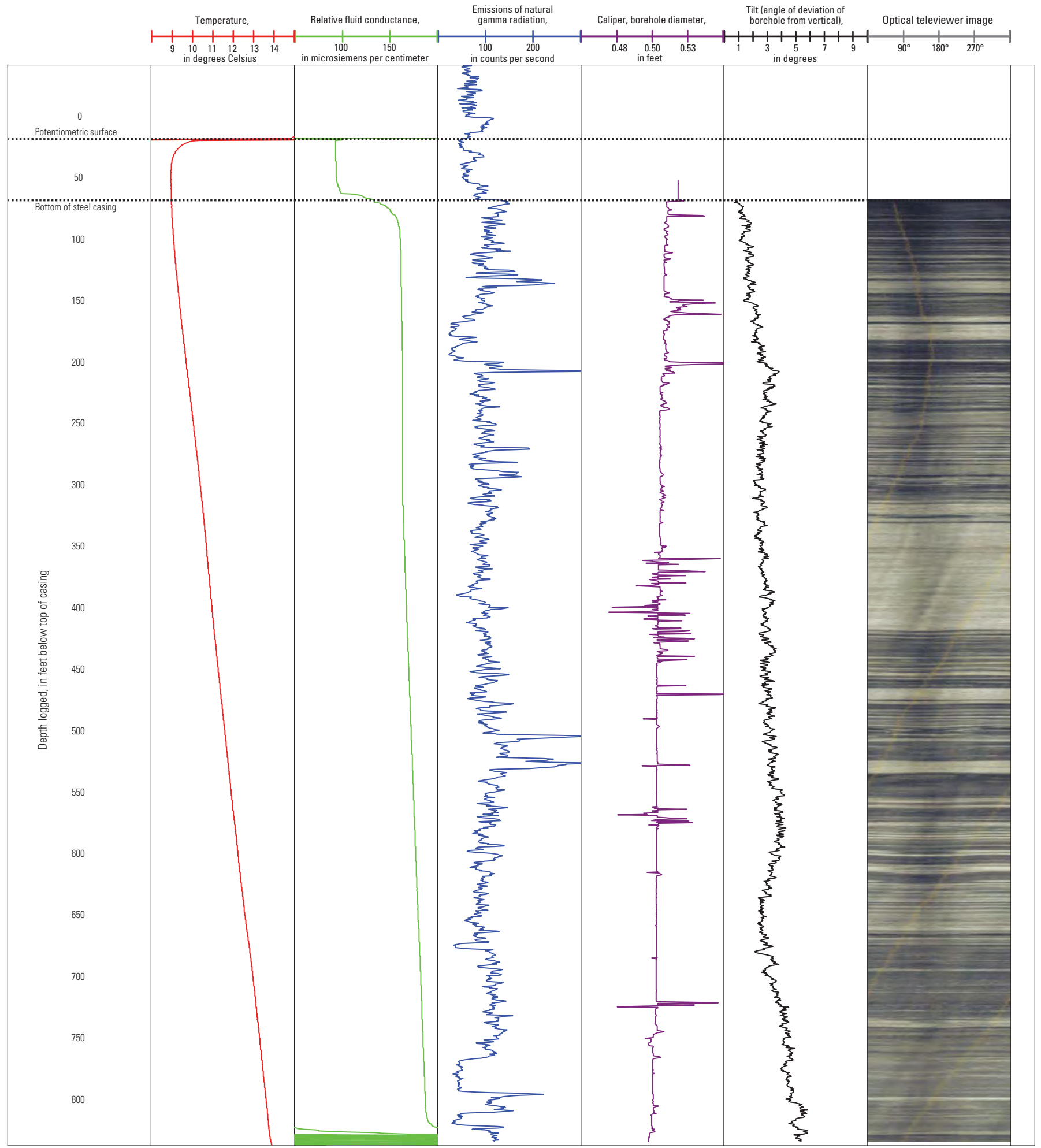

Figure 7. Bedrock well HRW 86 in Holderness, New Hampshire, 2013. 


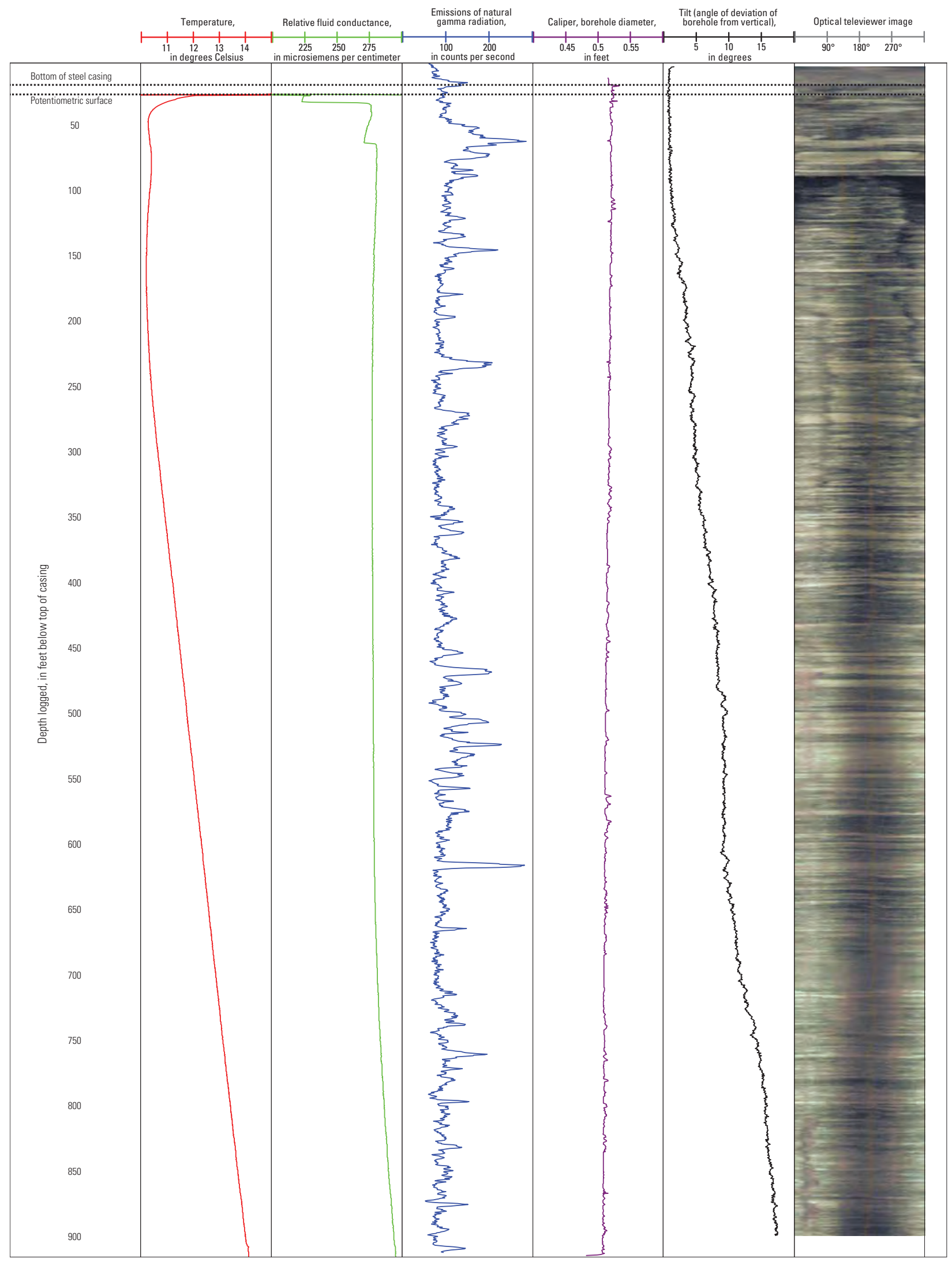

Figure 8. Bedrock well WPW 1068 in Windham, New Hampshire, 2013. 
Figures 2-11

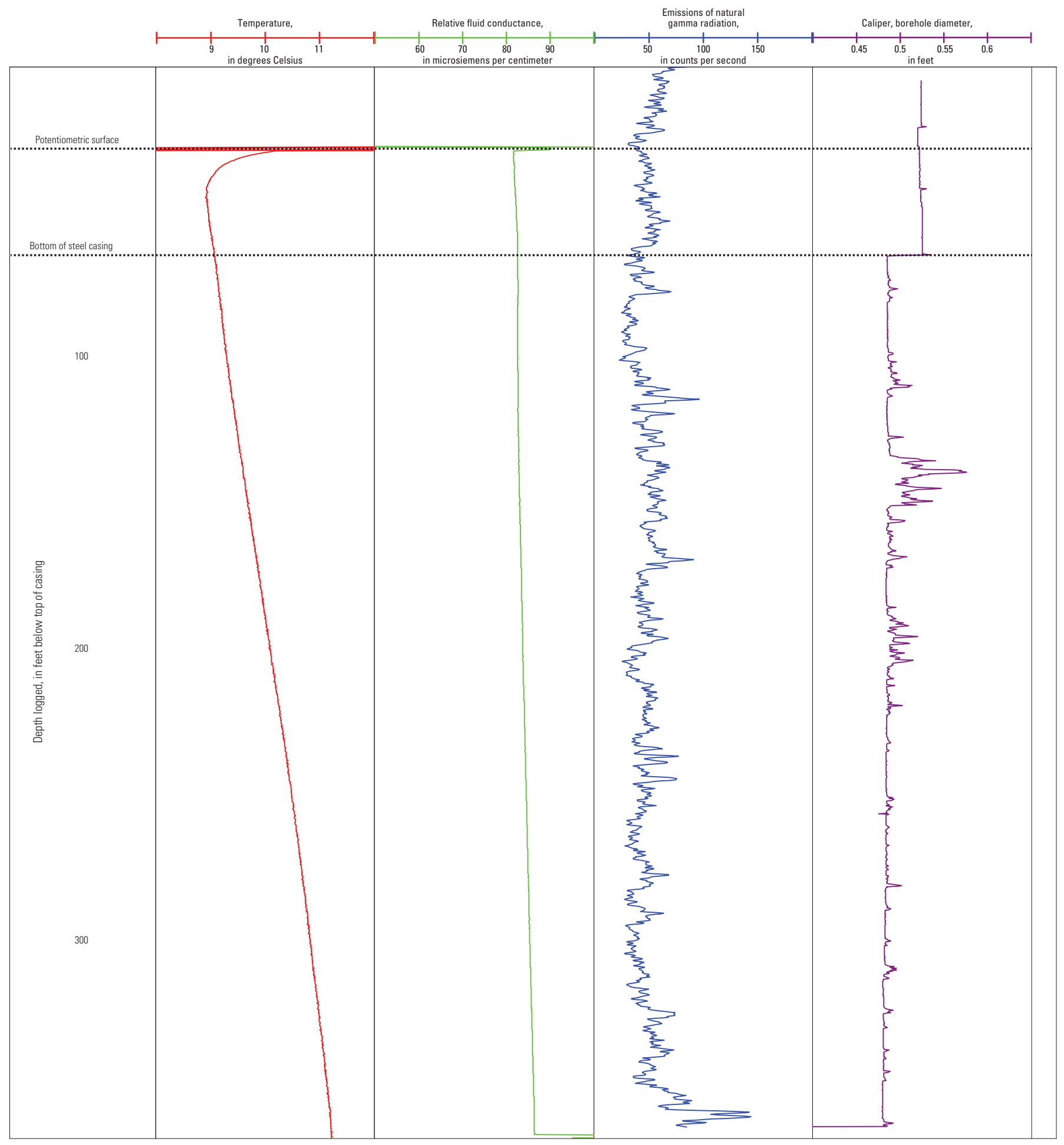

Figure 9. Bedrock well HUW 261 in Hopkinton, New Hampshire, 2013. 


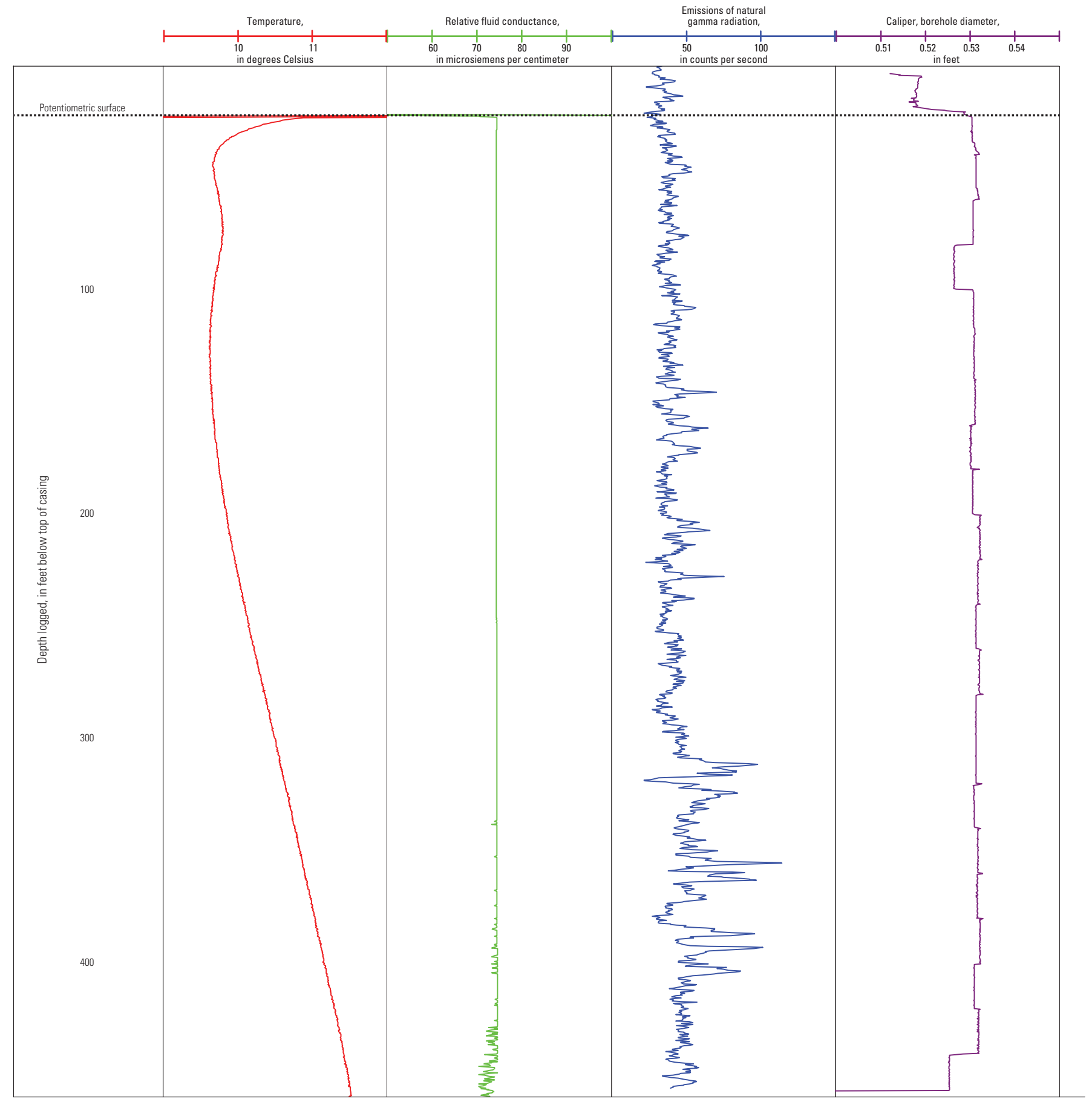

Figure 10. Bedrock well BBW 283 in Barrington, New Hampshire, 2013. Steel casing was present along the entire logged interval. 
Figures 2-11

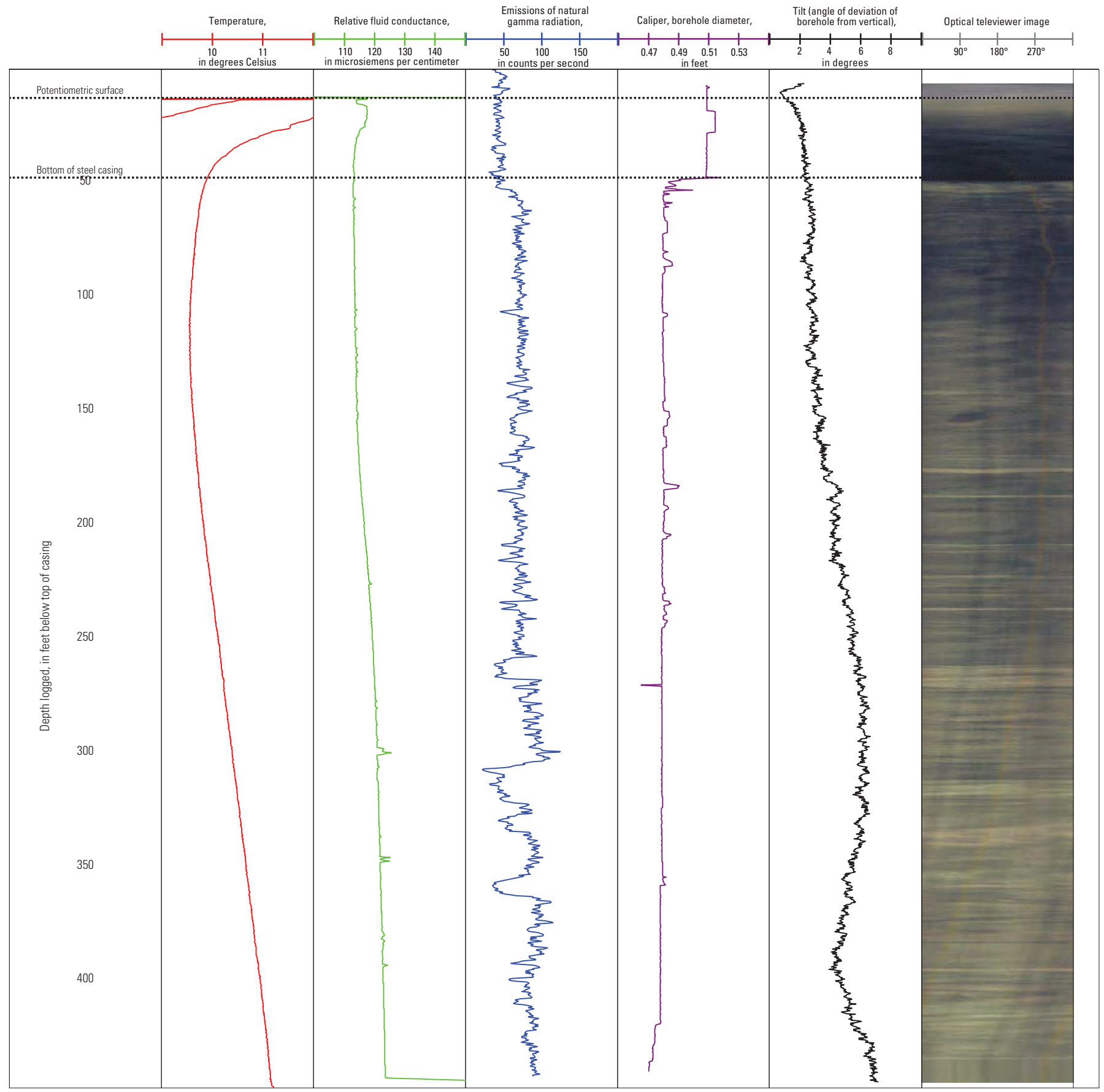

Figure 11. Bedrock well HUW 262 in Hopkinton, New Hampshire, 2013. 
THIS PAGE INTENTIONALLY LEFT BLANK 
Prepared by the Pembroke and West Trenton Publishing Service Center.

For more information concerning this report, contact:

Office Chief

U.S. Geological Survey

New England Water Science Center

New Hampshire-Vermont Office

331 Commerce Way, Suite 2

Pembroke, NH 03275

dc_nh@usgs.gov

or visit our Web site at:

http://nh.water.usgs.gov 


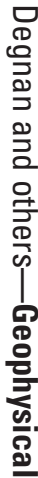

5

흠

동

윽

못

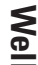

$\stackrel{5}{\circ}$

\%

울

홍

$\bar{a}$

\%

吾

을

\%

호․

훙

三'

疍

폭

킁

통

ㄴ.

虫 